Western North American Naturalist 70(1), (C) 2010, pp. 92-104

\title{
DIET AND HABITAT OF NORTHERN FLYING SQUIRRELS (GLAUCOMYS SABRINUS) IN THE BLACK HILLS OF SOUTH DAKOTA
}

\author{
Audrey Gabel ${ }^{1,5}$, Callie Ackerman ${ }^{1}$, Mark Gabel ${ }^{1}$, Elizabeth Krueger $^{2}$, Scott Weins ${ }^{3}$, and Linda Zierer ${ }^{1,4}$
}

\begin{abstract}
During the summers of 2005 and 2006, northern flying squirrels (Glaucomys sabrinus Shaw) were livecaptured in the northern Black Hills of South Dakota from mixed deciduous/coniferous and coniferous habitats. Squirrel captures were significantly correlated with volume of downed wood and number of snags. Diets were examined from scat collections ( $n=40$, deciduous/coniferous; $n=10$, coniferous). Number of fungal spores in the scat was significantly correlated with number of snags. From each scat collection, the frequencies of plant, animal, fungal, and unidentified components were determined. Hypogeous fungi were a frequent component of the diet, being found in $98.3 \%$ and $78.8 \%$ of the scat observed in 2005 and 2006. In 2006, as the frequency of dietary fungi decreased, the frequency of plant material increased from $<1.0 \%$ to $8.0 \%$ and frequency of unidentified material increased from $2.0 \%$ to $74.0 \%$. Animal content in the scat was negligible $(<1.0 \%$ to $1.0 \%)$. Rhizopogon was the most frequently occurring hypogeous fungus observed. Rhizopogon spores made up $97.9 \%$ of the spores counted in 2005 and $96.4 \%$ in 2006. Elaphomyces, Gautieria, Geopora, Hymenogaster, and Hysterangium were observed at much lower frequencies. Sporocarps were collected throughout the trapping periods. Fourteen were collected in 2005 and 12 in 2006. Of the 26 sporocarps collected, 11 were Rhizopogon, 4 Elaphomyces, 2 Gautieria, 1 Hymenogaster, 7 Hysterangium, and 1 Tuber. This study is the first to examine flying squirrel diets in the Black Hills and the first to report Elaphomyces, Gautieria, Hymenogaster, Hysterangium, Rhizopogon, and Tuber sporocarps from the South Dakota Black Hills.
\end{abstract}

Key words: hypogeous fungi, flying squirrels, diet, habitat, Black Hills, Glaucomys sabrinus, sporocarps.

Northern flying squirrels (Glaucomys sabrinus Shaw) occupy an important role in forests because they can locate, eat, and disperse viable spores of hypogeous fungi, promoting ectomycorrhizal relationships between the fungi and woody plants (Carey 1995, Carey et al. 2002, Caldwell et al. 2005). In the Pacific Northwest, flying squirrels have been described as a keystone species because, in addition to facilitating the mycorrhizal relationship, they are important prey for carnivores, including spotted owls, thus occupying an important link in the food chain (Meyer et al. 2007, Smith 2007, Weigl 2007). Smith (2007) indicates that knowledge of the species is still incomplete, especially in the northeastern United States, the southern Rocky Mountains, areas of the Sierra Nevada, and the Black Hills.

Habitat studies by Carey (1995) and Carey et al. (2002) determined that flying squirrel populations in Oregon and Washington were greater in old-growth forests with large trees, snags, fallen logs, and well-distributed ericaceous shrubs and greater in unthinned than in thinned forests. In Ontario, Canada, Holloway and Malcolm (2006) determined that northern flying squirrel density showed a strong relationship with tree density in older, undisturbed forests with snags. In the northwestern United States, Smith (2007) indicated that abundance was influenced by factors such as density of large trees, number of snags, shrub and canopy cover, and coarse woody debris. He also indicated that disturbance that reduces structural complexity reduces populations. Changes in forest practices, recreational activities in forests, and demand for forest products that modify size and arrangement of the home forest can be a threat to the flying squirrel population (Weigl 2007).

Hypogeous fungi have been documented in flying squirrel diets in various geographical regions, including the northwestern United States (Maser et al. 1986, Carey 1995, Colgan et al. 1997, Carey et al. 2002, and Lehmkuhl et al. 2004), northeastern (Currah et al. 2000) and western (Wheatley 2007) Alberta, West Virginia (Mitchell 2001), the Sierra Nevada of California

\footnotetext{
${ }^{1}$ Biology Department, Black Hills State University, Spearfish, SD 57799.

${ }^{2}$ USDA Forest Service, Bearlodge Ranger District, 121 S. 21st Street, Sundance, WY 82729.

${ }^{3}$ USDA Forest Service, Northern Hills Ranger District, 2014 North Main, Spearfish, SD 57783.

${ }^{4}$ Deceased.

${ }^{5}$ E-mail: audreygabel@bhsu.edu
} 
(Pyare and Longland 2000, Meyer et al. 2005), and central Idaho (Rosentreter et al. 1997). Furthermore, in western coniferous forests, these fungi (i.e., truffles) are major components of the diet and are preferred over other food items (Maser et al. 1986, Hall 1991, Rosentreter et al. 1997, Thysell et al. 1997, Currah et al. 2000, Lehmkuhl et al. 2004, Meyer and North 2005, and Smith 2007).

Spores in the scat or in stomach contents are used to evaluate diets. Some evidence indicates that scat studies are biased toward fungal spores because plants are more easily digested (Thysell et al. 1997). Currah et al. (2000) examined gut samples during the winter, and all but 7 of the 138 gut samples contained fungal spores, which were the single most abundant material in the gut. Hall (1991) evaluated both stomach contents and scat and found no significant differences in the genera of hypogeous fungi that were present.

Spores in the scat or in stomach contents usually can be identified to genus only, and sporocarps are collected to validate spore identifications (Castellano et al. 1989). Sporocarp surveys include those by Hunt and Trappe (1987), Amaranthus et al. (1994), Clarkson and Mills (1994), North and Greenberg (1998), Smith et al. (2001), Carey et al. (2002), and Lehmkuhl et al. (2004) in the Pacific Northwest; Loeb et al. (2000) in the Appalachians; Pyare and Longland (2002) and Meyer and North (2005) in the Sierra Nevada; and Waters et al. (1994) in Canada.

Very few sporocarp surveys have been conducted in habitats similar to the Black Hills of South Dakota, which are drier and dominated by Pinus ponderosa C. Lawson. States and Gaud (1997) collected sporocarps in northern Arizona, where precipitation ranges between 54 and $65 \mathrm{~cm}$ per year, which is similar to precipitation for the Black Hills, where annual precipitation ranges from $40 \mathrm{~cm}$ near the periphery to $70 \mathrm{~cm}$ in the north central hills (Trimarchi 1997). In eastern Washington, sporocarp richness was lowest in the open pine forests compared to young mixed forests and mature mixed forests (Lehmkuhl et al. 2004). States and Gaud (1997) reported that species richness, similarity, and abundance were lower in Arizona pine forests than in Pacific Northwest pine forests. From a drier Arizona habitat, States and Gaud (1997) sampled for 32 consecutive months and identified 16 species of hypogeous fungi. Common genera of Basidiomycota included Rhizopogon, Gautieria, Hysterangium, and Sclerogaster. Most common Ascomycota were Geopora and Tuber. States (1983) collected sporocarps of truffles in nearly pure stands of Pinus ponderosa in northern Arizona and western New Mexico. Balsamia magnata Harkn., Elaphomyces granulatus Fr., E. verrucosus C.W. Dodge, Tuber dryophilum Tul., T. levissimum Gilkey, and Geopora cooperi $\mathrm{f}$. cooperi Harkn. were listed as new records for Arizona. Eighteen species representing 10 genera of false truffles were collected by States (1984) in pure and mixed stands of Pinus ponderosa in northern Arizona. States (1983) referred to collections of Elaphomyces sp. under P. ponderosa in the Wyoming Black Hills. Castellano (1988) reported Hysterangium from western and north central Colorado and Hysterangium coriaceum Hesse with Pinus ponderosa in northeast (Crook County) Wyoming. Only one sporocarp of Hysterangium has been previously collected in the Black Hills of South Dakota (A.C. Gabel, Black Hills State University, unpublished data,). No studies of scat from flying squirrels have been conducted in the Black Hills.

The primary goal of this study was to examine from scat the diet of northern flying squirrels captured from a deciduous/coniferous and a coniferous habitat in the Black Hills of South Dakota. Based on literature from diet studies in other western forests (Maser et al. 1986, Hall 1991, Rosentreter et al. 1997, Thysell et al. 1997, Currah et al. 2000, Lehmkuhl et al. 2004, Meyer and North 2005, and Smith 2007), we hypothesize that hypogeous fungi will be a major part of the diet. Additionally, we hypothesize that hypogeous sporocarps collected in the area will reflect the diversity and frequency of genera found in the scat. We predicted that we would capture more squirrels from habitats with high occurrence of snags, understory vegetation, and coarse woody debris.

\section{Methods}

\section{Study Sites}

Sites were located from $44^{\circ} 25.160^{\prime} \mathrm{N}$ to $44^{\circ} 25.467^{\prime} \mathrm{N}$ latitude and from $103^{\circ} 56.455^{\prime} \mathrm{W}$ to $103^{\circ} 56.718^{\prime} \mathrm{W}$ longitude. Elevations ranged from 1661 to $1697 \mathrm{~m}$. Sites 1-3 sloped southeast or east, and sites 4-6 sloped west, southwest, or south. Slopes ranged from $9^{\circ}$ to $17^{\circ}$. Each of 

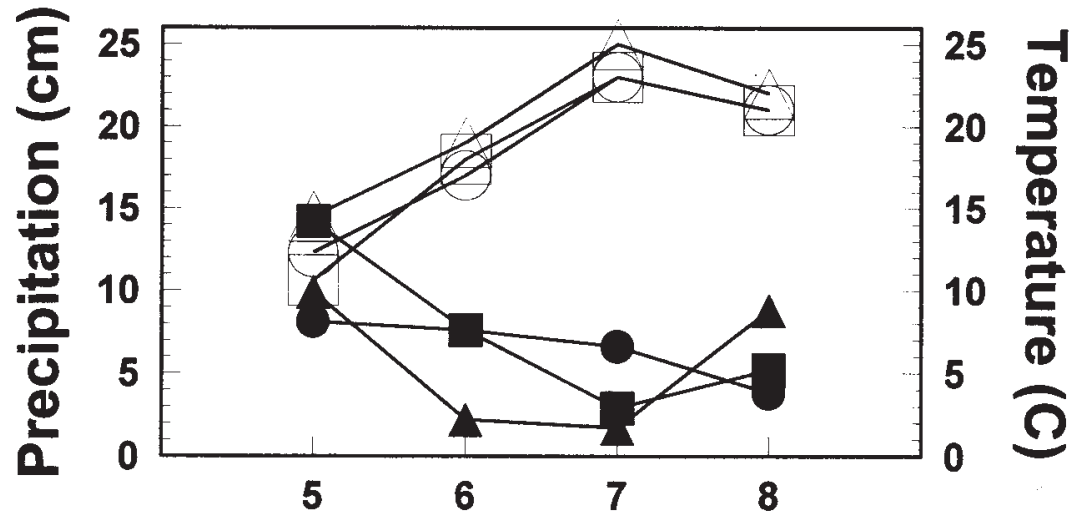

Month

Fig. 1. Average temperature $\left({ }^{\circ} \mathrm{C}\right)$ and precipitation $(\mathrm{cm})$ from the 2 closest cooperative weather stations to the study area for May-August 2005, 2006 and the previous 5 years. Open symbols are temperature, and solid symbols are precipitation. Squares are for 2005, triangles for 2006, and circles for the previous 5 years. The May 2006 reading is from only one station. Most of the August 2006 precipitation occurred after the last squirrel capture.

the 6 sites occupied approximately $1300 \mathrm{~m}^{2}$ and were located within an area of $2 \mathrm{~km}^{2}$ that is $11 \mathrm{~km}$ southwest of Spearfish, Lawrence County, South Dakota. Sites 1-3 were heavily grazed and located where much of the mature pine had been cut in the early 1990s. Sites 4-6 were located in an area that had less grazing pressure than sites $1-3$ and that had light thinning in the early 1990s. There were no signs of past fire in either area (Krueger 2004).

\section{Climate Data}

Temperature and precipitation data from South Dakota State University climatology web site were averaged from the 2 cooperative recording stations closest to the trapping area (Fig. 1). Most of the August 2006 precipitation arrived late in the month, after August 23, the last squirrel capture.

\section{Vegetation}

Study sites were marked with a 20-m radius around each of the 6 trap trees. Litter depth was determined at 5-, 10-, 15-, and 20-m intervals along $\mathrm{N}, \mathrm{S}, \mathrm{E}$, and $\mathrm{W}$ transects originating at the trap trees. The predominant litter composition (e.g., moss, bare ground, graminoids, conifer leaves, herbs, small woody debris $<10$ $\mathrm{cm}$ in diameter, or deciduous leaves) was noted at each litter sampling site. The percentage of herbaceous plant cover at each of the 6 trapping sites was determined to the nearest $10 \%$ (e.g., $0-10 \%, 11-20 \%$, etc.), as was the percentage of woody debris $<10 \mathrm{~cm}$ in diameter. The volume of woody debris $\geq 10 \mathrm{~cm}$ in diameter was calculated. Canopy density was determined using an optical densiometer with 4 readings taken at each trap tree and 3 readings at $20 \mathrm{~m}$ from the trees at each of the 4 cardinal directions. Height from ground to lowest canopy was estimated visually. Diameter at breast height (dbh) was determined for each tree $\geq 5 \mathrm{~cm}$ dbh in each plot. The percentage of shrub cover for each species was measured at each site using GPS to determine area. The number of snags at each site was noted. Using this information, maps were constructed with a GIS program. All vascular plant species were determined, and vouchers were deposited in the Black Hills State University Herbarium.

\section{Trapping and Scat Collection}

Traps (Tomahawk Model \#201, $40.6 \times 12.7$ $\times 12.7 \mathrm{~cm}$ ) modified to have a solid floor were set for 10 consecutive days (except during rain or cold weather) in June, July, August, and September during 2005 and in June, July, and August during 2006, with approximately 2 weeks between each trapping period. Twelve traps were set, of which 6 were placed in mixed deciduous/coniferous forests (sites 1-3) and 6 in coniferous forests (sites 4-6). At each site, one trap was placed in a tree approximately $120-150 \mathrm{~cm}$ above a second trap, which was 
placed on the ground. At dusk during trapping, the floor of each trap was wiped clean with $70 \%$ isopropyl alcohol, and then the traps were baited with tuna fish and set. Traps were checked early the next morning, and captured squirrels were released. Since the primary goal of this study was to determine the types of fungi utilized by northern flying squirrels, squirrels were not marked before release. Differences in size, coloration, ear notches, sex, and maturity made it apparent that numerous squirrels were trapped. Scat from each squirrel captured was collected and placed in $10 \%$ formalin. The numbers of squirrels trapped in tree traps and ground traps were not statistically different, so numbers were pooled.

\section{Determination of Diet from the Scat}

Approximately $0.2 \mathrm{~mL}$ of fecal pellet material was added to $0.5 \mathrm{~mL}$ of water and macerated (Colgan et al. 1997). This process was done 3 times to include fecal material from 3 pellets for each squirrel captured. For each suspension, a drop was placed on a microscope slide, and a surfactant (Pohl 1965) was added to cover the space under a $22 \times 22$-mm cover slip (i.e., 3 slides per squirrel). We observed 25 random microscope fields at $400 \mathrm{X}$ for each slide, resulting in 75 fields for the 3 slides from one squirrel collection (Colgan et al. 1997, Meyer et al. 2005). Using an ocular disc with a grid divided into 100 squares, we noted and recorded the number of squares occupied for each category: fungi, plants, animals, or unidentifiable material. Observing 75 fields of view at 400X, we counted the number of spores of each fungal genus occupying the grid and determined the frequency of each based on total number of spores in the grid.

Spores were identified to genus following Castellano et al. (1989) using standard lightmicroscope procedures and scanning electron microscopy (SEM) with a JEOL 5600 LV. Prior to SEM observation, spores were air-dried and coated with gold to make the samples conductive. Spores with insufficient morphological features or no sporocarps for validation were listed as not identified.

\section{Collection and Identification of Sporocarps}

Approximately $1200 \mathrm{~m}^{2}$ of soil in 2005 and approximately $440 \mathrm{~m}^{2}$ of soil in 2006 was manually removed and replaced to collect sporocarps. Soil was examined from the litter to approximately $15 \mathrm{~cm}$ deep or to a layer of rocks. Sporocarps were collected during trapping periods, which were 10 days in June, 10 days in July, 10 days in August, and intermittently at other times. Our climatic data (above) documented the xeric conditions in the Black Hills during the study. At the onset, collecting was at sites within a 20-m radius of traps, but very few sporocarps were collected. To improve discovery, collecting was extended to approximately $2 \mathrm{~km}$ in all directions for the sites from moister microhabitats and north-facing slopes. Identification of vegetation, distance from vegetation, depth below the surface of the litter and size, color, and attachment type were noted for each sporocarp collected. Sporocarps were brought to the laboratory and identified to genus or species using standard light-microscope procedures (Dodge and Zeller 1934, Gilkey 1939, Stewart 1974, States 1983, 1984, Arora 1986, Castellano 1988, Castellano et al. 1989, and States and Gaud 1997). Spores from some sporocarps were processed similarly to the spores from scat for observation by SEM on a JEOL 5600 LV. Sporocarps were not all identified to species because of inadequate collection or lack of necessary characters. Specimens in good condition were placed in the fungal collection housed in the Black Hills State University Herbarium.

\section{Data Analyses}

Cluster analysis and principal component analysis (NTSYSpc 2.2, Exeter Software, Setauket, NY) were used to compare the 6 sites based upon vegetation characteristics. Correlation of squirrel captures with vegetation parameters and correlation of the fungal spores in squirrel scat with vegetation parameters were calculated (Instat 3.0, Graphpad Software, Inc., San Diego, CA). Statistical significance was set at $P<0.05$.

\section{Results}

\section{Vegetation at Study Sites}

The vegetation parameters of the 6 sites are summarized in Table 1 and illustrated in Fig. $2(\mathrm{a}-\mathrm{f})$. Litter composition at sites 1-3 comprised several different plant materials, while sites 4-6 had conifer leaves (needles) as the major component of the litter. Overall herbaceous plant cover was lower at sites 4-6 than at sites 1-3, as was the volume of downed wood $>10 \mathrm{~cm}$ in diameter. Sites $4-6$ were 
TABLE 1. Vegetative characteristics at the 6 sites reported in this study. Litter abbreviations are as follows: $\mathrm{sm}$ wd $=$ small wood, con lvs $=$ conifer leaves, herb $=$ herbaceous. Number of trees and average $\mathrm{dbh}$ refer to trees $\geq 5 \mathrm{~cm} \mathrm{dbh}$. $\mathrm{NA}=$ only one tree $\geq 5 \mathrm{~cm}$ dbh present in site (i.e., no average).

\begin{tabular}{|c|c|c|c|c|c|c|}
\hline Variable & 1 & 2 & 3 & 4 & 5 & 6 \\
\hline Avg. litter depth, cm & 4.8 & 5.6 & 4.6 & 4.9 & 3.1 & 5.1 \\
\hline Major litter comp. (\%) & sm wd (38) & con lvs (44) & herb (44) & con lvs $(88)$ & con lvs $(63)$ & con lvs $(100)$ \\
\hline Herbaceous plant cover, $\%$ & $91-100$ & $91-100$ & $91-100$ & $61-70$ & $51-60$ & $61-70$ \\
\hline Small-diameter wood, \% & $11-20$ & $11-20$ & $11-20$ & $11-20$ & $0-10$ & $11-20$ \\
\hline Volume downed wood, $\mathrm{m}^{3}$ & 3 & 2.8 & 4.6 & 1.3 & 0.9 & 1.9 \\
\hline Canopy density, \% & 55.8 & 62.6 & 51 & 59.5 & 54.9 & 54 \\
\hline Height to canopy, m & $2-3$ & $2-3$ & $2-3$ & $2-8$ & $2-8$ & $2-8$ \\
\hline No. of pine (avg. dbh cm) & $29(19.4)$ & $50(17.5)$ & $33(16.5)$ & $56(22.3)$ & $106(18.4)$ & $52(29.1)$ \\
\hline No. of aspen (avg. dbh cm) & $12(8.7)$ & $4(8.7)$ & $45(6.8)$ & 0 & 0 & 0 \\
\hline No. of birch (avg. dbh cm) & 0 & $5(10.7)$ & 0 & 1 (NA) & 0 & 0 \\
\hline No. of oak (avg. dbh cm) & 1 (NA) & $12(12.6)$ & $3(15.5)$ & 0 & 0 & 1 (NA) \\
\hline Shrub aspen, $\%$ & 31.3 & 3 & 30.9 & $<1$ & $<1$ & $<1$ \\
\hline Shrub oak, \% & 8.2 & 1.7 & 0.2 & $<1$ & $<1$ & $<1$ \\
\hline Vascular plant species & 43 & 45 & 38 & 47 & 48 & 45 \\
\hline Snags & 4 & 5 & 8 & 0 & 0 & 1 \\
\hline
\end{tabular}

dominated by Pinus ponderosa C. Lawson (pine). The only other tree species with dbh $\geq$ $5 \mathrm{~cm}$ at sites $4-6$ were Betula papyrifera Marsh. (birch) at site 4 and Quercus macrocarpa Michx. (oak) at site 6. There were no Populus tremuloides Michx. (aspen) trees at sites 4-6. Immature aspen and oak shrubs were a major component of sites 1-3 (Fig. 2, a-c), with the combined percent cover of these shrubs ranging from $4.7 \%$ to $39.5 \%$, while the 2 species made up $<1 \%$ of shrub vegetation at sites $4-6$ (Fig. 2, d-f). Arctostaphylos uva-ursi (L.) Spreng., Juniperus communis L., Prunus virginiana L., and Symphoricarpos albus (L.) S.F. Blake were present at all sites. Shepherdia canadensis (L.) Nutt. was present at sites 4-6. A total of 90 vascular plant species were identified from all sites. Seventeen species were present at all 6 sites, while 28 species were present at only 1 site. Collectively, sites 1-3 had 17 snags, and sites 4-6 had 1 snag. Cluster analysis (Fig. 3) based on data in Table 1 provided a summary of the sites based on vegetation characteristics. Principal component analysis $(88.4 \%$ of the variability in the system was explained with the first 3 principal components) was used as a check on the cluster analysis but is not presented here because results were consistent with cluster analysis (Rohlf 2005).

\section{Squirrels Trapped}

In 2005, flying squirrels were trapped 24 times: 9 in June, 6 in July, and 9 in August. No squirrels were trapped in September. Flying squirrels were trapped 15 times from the deciduous/coniferous habitat (sites 1-3) and 9 times from the coniferous habitat (sites 4-6). Only one squirrel was trapped from site 5 , and no squirrels were trapped from site 6 . Flying squirrels were trapped 13 times in tree traps and 11 times in ground traps. In 2006, flying squirrels were trapped 26 times: 3 in June, 14 in July, and 9 in August. Flying squirrels were trapped 25 times in the deciduous/coniferous habitat (sites 1-3). Only one squirrel was trapped from site 4 , and no squirrels were trapped from sites 5 or 6 . Squirrels were trapped 16 times in tree traps and 10 times in ground traps. During the entire study, $80 \%$ of the captures were from the deciduous/coniferous habitat (sites 1-3). The number of squirrel captures in 2005 and 2006 compared to vegetation parameters showed that the only factors significantly correlated with number of captures were the volume of downed wood $(r=0.81, P$ $=0.049)$ and the number of snags $(r=0.84, P=$ $0.033)$.

\section{Flying Squirrel Diets}

For both years, fungi were the most frequent component of flying squirrel diets in the Black Hills. Plant and animal components did not approach the frequency of fungi. Plant components included stomata, epidermal cells, fibers, portions of tracheids and vessels, and P. ponderosa pollen. Animal components included pieces of exoskeletons, scales of butterfly wings, and nematodes. When the number of fungal spores in scat for both years was compared with vegetation parameters, the correlation was significant 

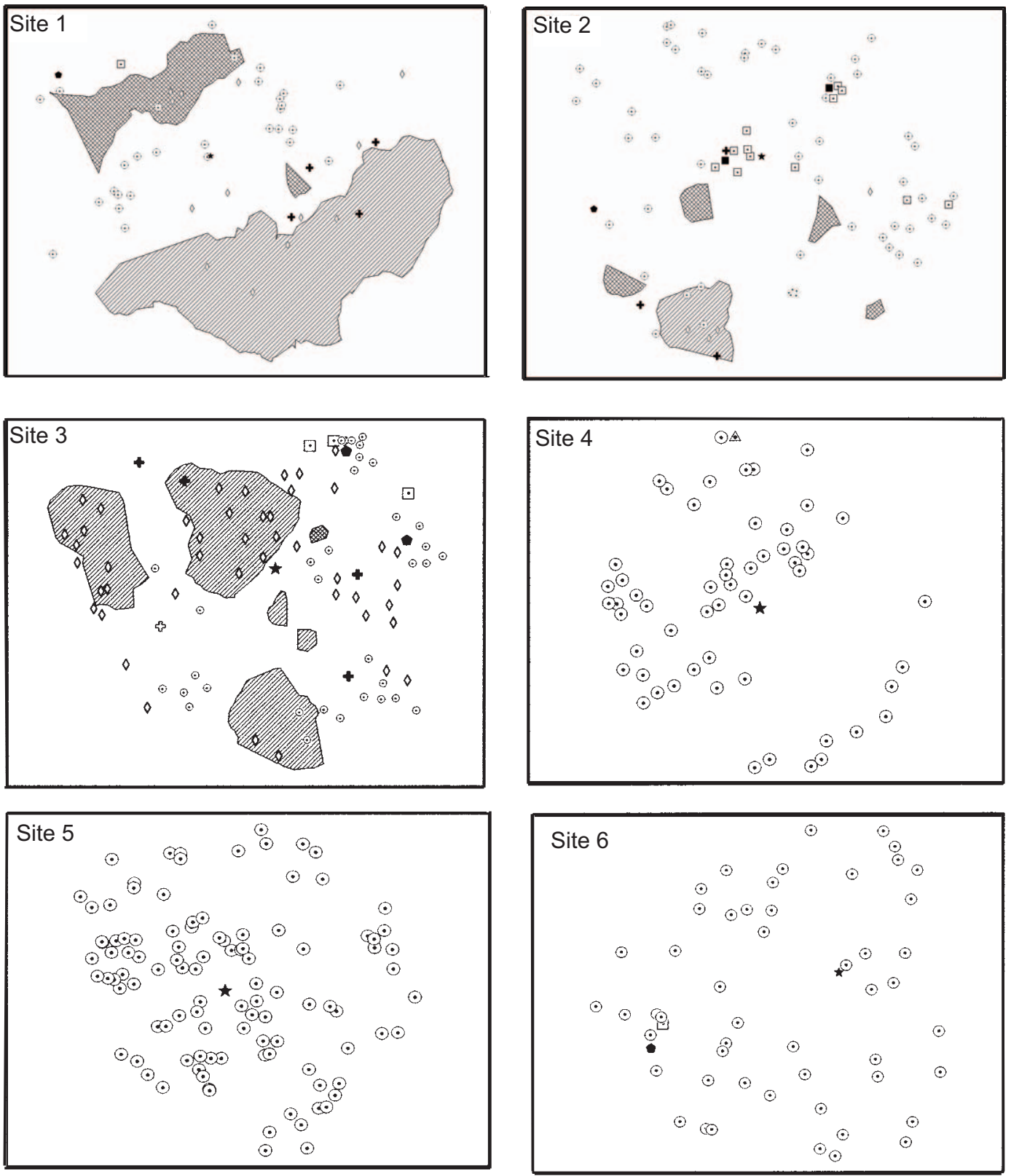

Fig. 2. a-f. Vegetation components for sites 1-6. Site 1 star $=$ trap in Pinus ponderosa; Site 2 star = trap in Quercus macrocarpa; Site 3 star $=$ trap in Populus tremuloides snag; Site $4-6$ stars $=$ traps in $P$. ponderos $a$; dot inside a circle $=P$. ponderos $a$ with $\mathrm{dbh} \geq 5 \mathrm{~cm}$; diamond $=P$. tremuloides with $\mathrm{dbh} \geq 5 \mathrm{~cm}$; dot inside a square $=Q$. macrocarpa with dbh $\geq 5 \mathrm{~cm}$; dot in triangle $=$ Betula papyrifera with $\mathrm{dbh} \geq 5 \mathrm{~cm}$; crosshatch $=$ group of $P$. tremuloides with $\mathrm{dbh}<5 \mathrm{~cm}$; double crosshatch $=$ group of $Q$. macrocarpa with $\mathrm{dbh}<5 \mathrm{~cm}$; black cross $=P$. tremuloides snag; pentagon $=P$. ponderosa snag; black square $=Q$. macrocarpa snag; open cross $=$ immediately adjacent $P$. ponderos $a$ and $P$. tremuloides snags. 


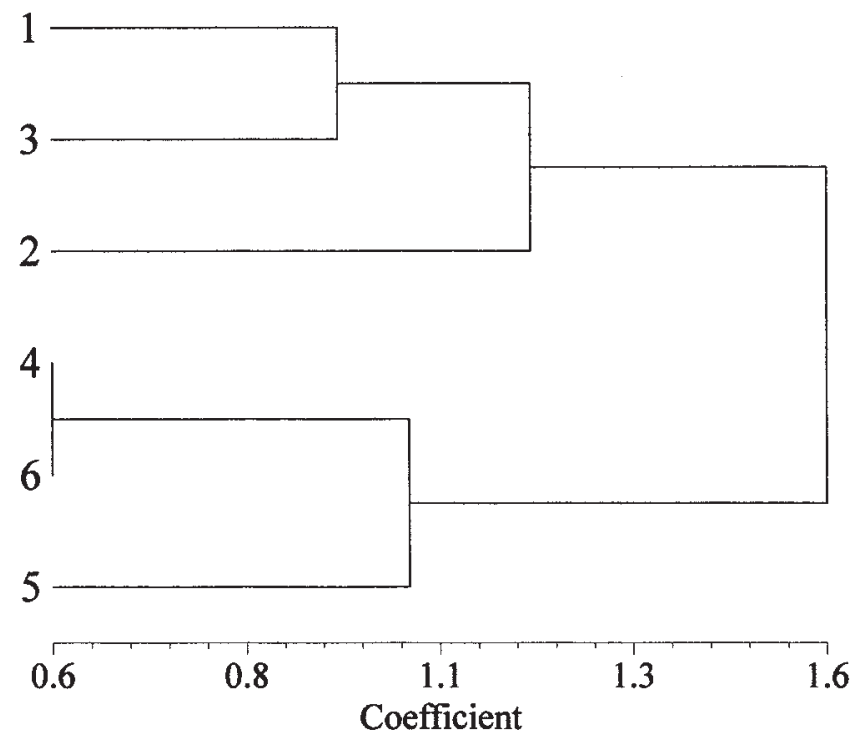

Fig. 3. Cluster analysis of sites using site parameters as variables.

TABLE 2. Scat samples observed with a gridded ocular at 400X. Total squares occupied, means, and percentages for diet categories for June, July, and August of 2005 and 2006. No ID = unidentified material. Number $(n)$ of collections consists of 75 microscope fields per capture. Means and percentages are rounded to whole numbers.

\begin{tabular}{|c|c|c|c|c|c|c|}
\hline Year & Month & Total & Fungi & Plant & Animal & No ID \\
\hline \multirow[t]{9}{*}{2005} & \multirow[t]{3}{*}{ June $(n=9)$} & $66,906^{\mathrm{a}}$ & 66,350 & 69 & 172 & 235 \\
\hline & & $7434^{\mathrm{b}}$ & 7372 & 8 & 19 & 26 \\
\hline & & & $99 \%$ & $<1 \%$ & $<1 \%$ & $<1 \%$ \\
\hline & \multirow{3}{*}{ July $(n=6)$} & 44,792 & 44,294 & 138 & 20 & 326 \\
\hline & & 7465 & 7382 & 23 & 3 & 54 \\
\hline & & & $99 \%$ & $<1 \%$ & $<1 \%$ & $<1 \%$ \\
\hline & \multirow[t]{3}{*}{ August $(n=9)$} & 53,097 & 51,263 & 165 & 93 & 1591 \\
\hline & & 5900 & 5696 & 18 & 10 & 177 \\
\hline & & & $97 \%$ & $<1 \%$ & $<1 \%$ & $3 \%$ \\
\hline \multirow[t]{9}{*}{2006} & \multirow[t]{3}{*}{ June $(n=3)$} & 20,950 & 20,461 & 20 & 13 & 427 \\
\hline & & 6983 & 6820 & 7 & 4 & 142 \\
\hline & & & $99 \%$ & $<1 \%$ & $<1 \%$ & $2 \%$ \\
\hline & \multirow{3}{*}{ July $(n=14)$} & 71,149 & 61,261 & 3081 & 227 & 6599 \\
\hline & & 5082 & 4376 & 220 & 16 & 471 \\
\hline & & & $86 \%$ & $4 \%$ & $<1 \%$ & $9 \%$ \\
\hline & \multirow[t]{3}{*}{ August $(n=9)$} & 14,696 & 2521 & 1100 & 162 & 10,935 \\
\hline & & 1633 & 280 & 122 & 18 & 1215 \\
\hline & & & $17 \%$ & $8 \%$ & $1 \%$ & $74 \%$ \\
\hline
\end{tabular}

Total squares occupied

bMean

only for the number of snags $(r=0.82, P=$ 0.047 ). For 2006 , the number of spores was highly correlated with the volume of downed wood $(r=0.92, P=0.009)$.

In 2005, fungi composed $99.2 \%$ of the scat in June, $98.8 \%$ in July, and 96.5\% in August (Table 2). Plant, animal, and unidentified material combined composed $<1 \%$ each month, except for unidentified material in August.
Fungi in 2006 composed $98.7 \%$ of scat in June, $86.1 \%$ in July, and $17.2 \%$ in August. Percent of plant and unidentified material increased during July and August when percent of fungi decreased. Animal content composed $\leq 1 \%$.

Rhizopogon was the most common genus observed for both years of the study (Table 3). In 2005 , Rhizopogon composed $97.8 \%$ of 
TABLE 3. Total number of spores counted, means, and percentages for genera or groups of fungi observed in the scat for June, July, and August of 2005 and 2006. Rhiz $=$ Rhizopogon, Hyme $=$ Hymenogaster , Geop $=$ Geopora, Hyst $=$ Hysterangium, Elap $=$ Elaphomyces, Gaut $=$ Gautieria, $\mathrm{Myc}=$ mycelium, and No ID $=$ unidentified fungal spores. Number $(n)$ of collections consists of 75 microscope fields per capture. Means and percentages are rounded to whole numbers.

\begin{tabular}{|c|c|c|c|c|c|c|c|c|c|c|}
\hline Year & Month & Total & Rhiz & Hyme & Geop & Hyst & Elap & Gaut & Мyc & $\overline{\text { No ID }}$ \\
\hline \multirow[t]{9}{*}{2005} & June $(n=9)$ & $137,033^{a}$ & 134,044 & 15 & 53 & 806 & 0 & 0 & 147 & 1964 \\
\hline & & $15,226^{\mathrm{b}}$ & 14,894 & 2 & 6 & 90 & 0 & 0 & 16 & 218 \\
\hline & & & $98 \%$ & $<1 \%$ & $<1 \%$ & $<1 \%$ & $0 \%$ & $0 \%$ & $<1 \%$ & $1 \%$ \\
\hline & July $(n=6)$ & 81,764 & 80,682 & 0 & 14 & 803 & 0 & 10 & 18 & 178 \\
\hline & & 13,627 & 3447 & 0 & 2 & 134 & 0 & 2 & 3 & 30 \\
\hline & & & $99 \%$ & $0 \%$ & $<1 \%$ & $1 \%$ & $0 \%$ & $<1 \%$ & $<1 \%$ & $<1 \%$ \\
\hline & August $(n=9)$ & 134,888 & 131,852 & 1 & 6 & 546 & 24 & 278 & 181 & 2281 \\
\hline & & 14,988 & 14,650 & $<1$ & $<1$ & 61 & 3 & 31 & 20 & 253 \\
\hline & & & $98 \%$ & $<1 \%$ & $<1 \%$ & $<1 \%$ & $<1 \%$ & $<1 \%$ & $<1 \%$ & $2 \%$ \\
\hline \multirow[t]{9}{*}{2006} & June $(n=3)$ & 62,525 & 62,165 & 0 & 51 & 1 & 7 & 0 & 11 & 300 \\
\hline & & 20,842 & 20,722 & 0 & 17 & $<1$ & 2 & 0 & 4 & 100 \\
\hline & & & $99 \%$ & $0 \%$ & $<1 \%$ & $<1 \%$ & $<1 \%$ & $0 \%$ & $<1 \%$ & $<1 \%$ \\
\hline & July $(n=14)$ & 188,303 & 184,202 & 13 & 126 & 439 & 124 & 454 & 687 & 2210 \\
\hline & & 13,450 & 13,157 & $<1$ & 9 & 31 & 9 & 32 & 49 & 58 \\
\hline & & & $98 \%$ & $<1 \%$ & $<1 \%$ & $<1 \%$ & $<1 \%$ & $<1 \%$ & $<1 \%$ & $1 \%$ \\
\hline & August $(n=9)$ & 2522 & 266 & 0 & 41 & 1517 & 47 & 0 & 462 & 184 \\
\hline & & 280 & 30 & 0 & 5 & 169 & 5 & 0 & 51 & 20 \\
\hline & & & $11 \%$ & $0 \%$ & $2 \%$ & $60 \%$ & $2 \%$ & $0 \%$ & $18 \%$ & $7 \%$ \\
\hline
\end{tabular}

Total number counted

bMeans

TABLE 4. Total numbers of spores counted, means, and percentages for fungal genera and other groups of fungi observed in the scat, summarized by habitat and by year. Rhiz = Rhizopogon, Hyme = Hymenogaster, Geop = Geopora , Hyst $=$ Hysterangium, Elap $=$ Elaphomyces, Gaut $=$ Gautieria , Myc $=$ mycelium, and No ID $=$ fungal spores not identified. Dec $=$ deciduous and con $=$ coniferous. Number $(n)$ of collections consists of 75 microscope fields per capture. Means and percentages are rounded to whole numbers.

\begin{tabular}{|c|c|c|c|c|c|c|c|c|c|c|}
\hline Year & Habitat & Rhiz & Hyme & Geop & Hyst & Elap & Gaut & Myc & No ID & Total \\
\hline \multirow[t]{6}{*}{2005} & $\mathrm{dec} / \operatorname{con}(n=15)$ & $222,301^{\mathrm{a}}$ & 6 & 67 & 1942 & 24 & 14 & 272 & 1339 & 225,968 \\
\hline & & $14,820^{\mathrm{b}}$ & 1 & 5 & 130 & 2 & 1 & 18 & 89 & 15,066 \\
\hline & & $98 \%$ & $<1 \%$ & $<1 \%$ & $<1 \%$ & $<1 \%$ & $<1 \%$ & $<1 \%$ & $<1 \%$ & $100 \%$ \\
\hline & $\operatorname{con}(n=9)$ & 124,337 & 0 & 6 & 213 & 0 & 274 & 74 & 3084 & 127,717 \\
\hline & & 13,815 & 0 & 1 & 24 & 0 & 30 & 8 & 343 & 14,191 \\
\hline & & $97 \%$ & $0 \%$ & $<1 \%$ & $<1 \%$ & $0 \%$ & $<1 \%$ & $<1 \%$ & $<1 \%$ & $100 \%$ \\
\hline \multirow[t]{6}{*}{2006} & $\mathrm{dec} / \operatorname{con}(n=25)$ & 246,623 & 13 & 220 & 1955 & 178 & 454 & 1160 & 2645 & 253,300 \\
\hline & & 9865 & 1 & 9 & 78 & 7 & 18 & 46 & 106 & 10,132 \\
\hline & & $98 \%$ & $<1 \%$ & $<1 \%$ & $<1 \%$ & $<1 \%$ & $<1 \%$ & $<1 \%$ & $<1 \%$ & $100 \%$ \\
\hline & con & 0 & 0 & 0 & 0 & 0 & 0 & 0 & 50 & 50 \\
\hline & & 0 & 0 & 0 & 0 & 0 & 0 & 0 & 50 & 50 \\
\hline & & $0 \%$ & $0 \%$ & $0 \%$ & $0 \%$ & $0 \%$ & $0 \%$ & $0 \%$ & $100 \%$ & $100 \%$ \\
\hline
\end{tabular}

aTotal number counted

bMeans

fungi in June, $98.7 \%$ in July, and $97.7 \%$ in August. Elaphomyces, Gautieria, Geopora, Hymenogaster, Hysterangium, mycelium, and unidentified fungal spores occurred infrequently at low percentages. In 2006, Rhizopogon composed $99.4 \%$ of fungi in June, $97.8 \%$ in July, and $10.5 \%$ in August. Hysterangium was infrequent until August when it increased to $60.2 \%$ of fungi; fungal mycelium also increased to $18.3 \%$ of fungi in August. It should be noted that the total number of fungal spores counted in the grid decreased in August.

In 2005, Rhizopogon occurred most frequently from both the deciduous/coniferous and coniferous habitats, but other genera were represented (Table 4). In 2006, Rhizopogon was also the most frequent genus in the scat from the deciduous/coniferous habitat, though other genera were present; only one collection was obtained from the coniferous habitat, and fungi were unidentifiable. 
TABLE 5. Number, genera, and species of sporocarps collected by date and habitat.

\begin{tabular}{|c|c|c|c|}
\hline Taxon & Sporocarps & Date & Habitat \\
\hline \multicolumn{4}{|l|}{ Ascomycota } \\
\hline Elaphomyces & 3 & 15 September 2005 & deciduous/coniferous \\
\hline Elaphomyces & 1 & 20 September 2005 & deciduous/coniferous \\
\hline Tuber levissimum Gilkey & 1 & 9 August 2005 & deciduous/coniferous \\
\hline \multicolumn{4}{|l|}{ Basidiomycota } \\
\hline Gautieria crispa Stewart \& Trappe & 2 & 16 June 2005 & coniferous \\
\hline Hymenogaster subalpinus Smith & 1 & 21 June 2006 & deciduous/coniferous \\
\hline Hysterangium coriaceum Hesse & 1 & 2 June 2005 & deciduous/coniferous \\
\hline Hysterangium coriaceum Hesse & 6 & 4 August 2006 & deciduous/coniferous \\
\hline Rhizopogon & 1 & 21 June 2005 & deciduous/coniferous \\
\hline Rhizopogon & 1 & 28 July 2005 & deciduous/coniferous \\
\hline Rhizopogon & 1 & 3 August 2005 & coniferous \\
\hline Rhizopogon & 1 & 9 August 2005 & coniferous \\
\hline Rhizopogon & 1 & 10 August 2005 & deciduous/coniferous \\
\hline Rhizopogon & 1 & 16 August 2005 & deciduous/coniferous \\
\hline Rhizopogon & 5 & 15 August 2006 & coniferous \\
\hline
\end{tabular}

\section{Sporocarps Collected}

Sporocarps were collected from $15 \mathrm{~cm}$ to $2.70 \mathrm{~m}$ from $P$. ponderosa and at the litter/soil interface or $2.5-5 \mathrm{~cm}$ below the interface (Table 5). Fourteen specimens were collected in 2005 and 12 in 2006. Eleven of the collections were of Rhizopogon, 4 were Elaphomyces, 2 Gautieria, 1 Hymenogaster, 7 Hysterangium, and 1 Tuber. All genera were also observed in the scat except for Tuber. During the study, we collected 26 sporocarps from over $1640 \mathrm{~m}^{2}$ of soil uncovered.

\section{DisCUSSION}

\section{Vegetation}

Comparisons of our results with other published works show differences in habitat correlations with number of fungal spores from scat and with number of captures. Lemkuhl et al. (2004) reported that truffle diversity and biomass are lower in open ponderosa pine forests than in other mixed forest types. These differences could explain our low capture numbers for squirrels in the open pine forest sites (4-6). Meyer et al. (2007) found that the capture of northern flying squirrels was greater with increased canopy cover and increased litter depth. Neither of those factors was significant in our study. Gomez et al. (2005) reported that in Oregon, thinning does not have an influence on density, survival, or body mass of squirrels; however, Carey (1995) found that the abundance of G. sabrinus could be predicted by the abundance of ericaceous shrubs, especially shrubs covering more than
$40 \%$ of the area. In our study, the abundance of spores in scat and the number of squirrel captures were not correlated with the percentage of shrub cover.

Abundance of spores in the scat was correlated with number of snags, and number of squirrel captures was correlated with number of snags and amount of downed wood. Density of snags from our study sites ranged from 0 (sites 4 and 5) to 62 (site 3) snags per hectare. Carey (1995) reported that a major predictor of northern flying squirrel density on the Olympic Peninsula was the presence of snags with a minimum density of 7 snags per hectare. Holloway and Malcolm (2006) reported that squirrel density had a strong positive relationship with snag density in conifer sites. Sites 1-3 had more area occupied by understory cover, and Pyare and Longland (2002) showed that squirrels preferred microhabitats in closer proximity to understory cover. Although we did not mark squirrels and although repeat trappings of some squirrels may have occurred, the high number of snags and large amount of downed wood at sites 1-3 may be responsible for the trapping success at these sites.

\section{Fungi in Scat}

This is the first report of Elaphomyces, Gautieria, Geopora, Hymenogaster, Hysterangium, and Rhizopogon spores identified from scat of flying squirrels trapped in the Black Hills of South Dakota. Data from the present 2-year study in the northern Black Hills indicate that these fungi are a major component of the diet of northern flying squirrels. Scat 
collections from a 2005 flying squirrel population study in Pennington and Custer counties in the central Black Hills also showed hypogeous fungi as the major component of northern flying squirrel diets, except for the June 3-15 collections, where the plant component was higher than fungal component (scats donated by M. Hough of South Dakota State University to A. Gabel who evaluated them, unpublished data). Most of the plant component was $P$. ponderosa pollen, corresponding with the peak of $P$. ponderosa pollination in the Black Hills. The pollen in the scat was intact, so it was difficult to determine if the squirrels ate pollen cones or if the wind-dispersed pollen was deposited on the scat after collection. However, Weigl (2007) mentions that in the southern Appalachians, staminate cones of fir and spruce are important foods in the spring. After June 16 , fungi were consistently the major part of the diet and closely matched results of the present study that started on 21 June 2005.

In 2005 , the fungal component was high throughout the season. However, in 2006, the fungal component decreased significantly during August, with increases in plant material and unidentifiable material. It is possible that in 2006, the warmer and drier season was poor for sporocarp production, and fewer numbers were available (Fig. 1). Hot, dry conditions especially in July and August 2006 may have decreased the olfactory prowess of the squirrels and their foraging abilities. Results from studies of other rodents showed that olfactory prowess is reduced in drier conditions and results in poorer foraging (Vander Wall 1998, 2000). Our results documenting hypogeous fungi as a major part of flying squirrel diets throughout most of the summer in the northern Black Hills, as evident from scat, support previous studies documenting frequent fungal consumption by flying squirrels during summer months (Maser et al. 1986, Carey 1995, Colgan et al. 1997, Rosentreter et al. 1997, Currah et al. 2000, Pyare and Longland 2000, Mitchell 2001, Carey et al. 2002, Lehmkuhl et al. 2004, and Meyer et al. 2005). All fungal genera observed in the scat have been reported from temperate, coniferous forests in North America (Maser et al. 1986, Hunt and Trappe 1987, Castellano et al. 1989, Hall 1991, Carey 1995, Rosentreter et al. 1997, Currah et al. 2000, Mitchell 2001, Smith et al. 2001, and Lehmkuhl et al. 2004).
Rhizopogon was the most frequent genus in the scat for most of the study and is commonly associated with members of Pinaceae (Castellano et al. 1989). The spores are very similar to spores of the bolete, Suillus granulatus (Fr.) Kuntze, which was also collected in the trapping area, and it is difficult to separate them even at SEM magnification and resolution. In water mounts, S. granulatus spores had a dilute yellow/tan pigment, and Rhizopogon spores were colorless. Slides of scat frequently displayed Rhizopogon spores in tight clumps which were similar in size and shape to the locules in which the hypogeous spores are produced. Suillus granulatus spores are forcibly released from basidia and typically have asymmetrical attachment scars. Rhizopogon spores are passively released and have symmetrical attachment scars. Scanning electron micrographs of several of our collections that were identified as Rhizopogon show spores with symmetrical scars. Johnson (1996) reported that Bruns et al. (1989) looked at mtDNA and found less genetic difference between Suillus (Boletaceae) and Rhizopogon (formerly Hymenogastraceae) than between Suillus and 2 other members of Boletaceae.

Some spores looked similar to spores of the epigeous mushroom Cortinarius, and its spores are very similar to the hypogeous/secotioid fungus Thaxterogaster. However, Thaxterogaster is not common in $P$. ponderosa forests, and no sporocarps of either genus were observed. Although no sporocarps of Geopora were collected, spores were observed in the scat. These spores are similar to epigeous ascomycetes, but Castellano et al. (1989) indicated that squirrels typically eat only the hypogeous ascomycetes. Because Geopora is listed as common in North American coniferous forests, we have identified our collections as Geopora. Spores from fungi in the Russulales were frequently collected late in the summer. Both hypogeous and epigeous fungi are in this order, and species of Russula, an epigeous mushroom, were collected in the trapping area. Other unidentified fungal spores were frequently observed and could be from epigeous basidiomycetous fungi eaten by the squirrels or could be miscellaneous fungal spores passively falling from air currents.

\section{Sporocarp Collections}

This study is the first report of Elaphomyces, Gautieria, Hymenogaster, Hysterangium, 
Rhizopogon, and Tuber sporocarps collected from the Black Hills of South Dakota. The 26 sporocarps of hypogeous fungi collected represent 6 genera. Tuber levissimum and Hymenogaster subalpinus were collected once, Gautieria crispa twice, Elaphomyces sp. 4 times, and Hysterangium coriaceum 7 times. The remaining collections were Rhizopogon spp. Although most fungal species were rarely collected, our results agree with results from Meyer and North (2005), who reported that almost half of the species in their study were rarely encountered. In our study, nearly two-thirds of the sporocarps were collected from mixed deciduous/coniferous habitats. Lehmkuhl et al. (2004) compared young and mature mixed forests with open pine forests and reported sporocarp richness lowest in the open pine forests. States and Gaud (1997) reported lower species richness, similarity, and abundance in Arizona $P$. ponderosa forests than in forests in the Pacific northwest.

The frequency of our sporocarp collection was low compared to most studies. Meyer et al. (2005) uncovered $1800 \mathrm{~m}^{2}$ and collected a total of 206 specimens in the Sierra Nevada, California, where annual precipitation is 110 $\mathrm{cm}$-almost twice as much as in the Black Hills. However, precipitation in the Sierra Nevada was $<1 \mathrm{~cm}$ during the summers of their study. Perhaps annual precipitation is as equally important as summer precipitation for sporocarp development. Comparing riparian sites with upland sites in the Sierra Nevada, Meyer and North (2005) uncovered a total of $800 \mathrm{~m}^{2}$ of soil and collected 313 and 76 truffles, respectively. The drier climate of the Black Hills may be responsible for the lower numbers collected, and the temperatures in the Black Hills were warmer and moisture was less abundant during the summer months of 2005-2006 compared to the previous 5 -year average. In 2006, precipitation for June and July was extremely low, and the August precipitation arrived too late to support sporocarp development. Lehmkuhl et al. (2004) determined that peak collection time in eastern Washington was in the spring when more moisture was present. Hunt and Trappe (1987) indicated that sporocarp production was dependent on temperature and precipitation patterns and that requirements differed between spring and fall. In southwestern Oregon, Maser et al. (1986) found that the best collecting season was April-May, and collections decreased as precipitation decreased during June-August. Collecting sporocarps in northern Arizona forests, States and Gaud (1997) determined that production was initiated when mean air temperature was greater than $8^{\circ} \mathrm{C}$ and when single precipitation amounts were $>1.5 \mathrm{~cm}$. In the Sierra Nevada, Meyer and North (2005) documented higher sporocarp frequency in the spring. Our study is the first to examine sporocarp diversity and frequency in the Black Hills. Although we collected more sporocarps later in the season, the numbers we collected during the study are too few to indicate an optimum season.

Sporocarps of Hysterangium were identified as $H$. coriaceum Hesse, which is a commonly collected species in North America, has been reported from Crook County, Wyoming, and is associated with species of Pinus (Castellano 1988). The one Tuber specimen was T. levissimum Gilkey, which States (1983) described and also collected under $P$. ponderosa in northern Arizona and western New Mexico. Gautieria sporocarps were G. crispa Stewart and Trappe, and the single Hymenogaster sporocarp was H. subalpinus Smith, both described by States (1984). States (1983) collected 2 species of Elaphomyces under P. ponderosa in northern Arizona and western New Mexico, and he also mentions Elaphomyces collections in the Wyoming Black Hills. However, our 2 collections do not have echinulate spores as described for States' (1983) species. States (1984) described several species of Rhizopogon, a very common genus in North America, collected from mixed stands of $P$. ponderosa in Arizona. Characters for identification of Rhizopogon were missing from our collections. It is possible our specimens represent more than one species.

Although we collected very few sporocarps, the squirrels were successful in locating them during the entire 2005 trapping season and most of the 2006 season. There is some evidence (Maser et al. 1986, Hall 1991, and Vernes et al. 2004) that flying squirrels stockpile sporocarps, but with deep snow cover in the hills during most winters, it seems reasonable that most of the stockpile would be consumed during the winter months, necessitating active searching for sporocarps during the summer. Hall (1991) identified Elaphomyces, Gautieria, Geopora, Hysterangium, and Rhizopogon in scat during winter trapping with continued snow cover in California and saw no evidence 
of digging in the snow to retrieve sporocarps. Maser et al. (1986) identified 20 genera of hypogeous fungi in scat collected from December to February in southwest Oregon. In New Brunswick, Vernes et al. (2004) examined diet during all seasons. They found more fungi in the diet during the summer, but samples from all seasons contained hypogeous taxa.

The hypogeous fungi, flying squirrels, and conifers exemplify an important 3-way mutualistic relationship. Squirrels eat hypogeous fungi and disperse the spores in their scat, which later germinate and establish ectomycorrhizal relationships with members of Pinaceae. This 3-way relationship increases availability of minerals for the trees, permitting them to grow more vigorously. Forest managers should strongly consider maintaining snags within the forest and an adequate volume of downed wood on the forest floor to ensure the long-term health of the forest.

\section{ACKNOWLEDGMENTS}

The authors dedicate this paper to the memory of Linda Zierer, an undergraduate student, employee, and research partner. We greatly miss her enthusiasm and curiosity about living things. We thank the U.S. Fish and Wildlife Service Federal Assistance Project T-14-R, \#2414 for support of this research and the South Dakota Game, Fish and Parks for assistance in administering the grant. Black Hills State University provided laboratory facilities. We thank Melissa Hough, South Dakota State University, for her contribution of scat collected from the central Black Hills. We appreciate the support of Mike Barnes. Suggestions on truffle collecting and identification from Lois Tiffany and Rosanne Healy, Iowa State University, were greatly appreciated. We thank Marc Meyer for thoughtful suggestions on an earlier version of this work.

\section{Literature Cited}

Amaranthus, M., J.M. Trappe, L. Bednar, and D. Arthur. 1994. Hypogeous fungi production in mature Douglas-fir forest fragments and surrounding plantations and its relation to coarse woody debris and animal mycophagy. Canadian Journal of Forestry Research 24:2157-2165.

Arora, D. 1986. Mushrooms demystified. 2nd edition. Ten Speed Press, Berkeley, CA. 959 pp.

Bruns, T.D., R. Fogel, T. White, and J. Palmer. 1989. Accelerated evolution of a false truffle from a mushroom ancestor. Nature 339:140-142.
Caldwell, I.R., K. Vernes, and F. Barlocher. 2005. The northern flying squirrels (Glaucomys sabrinus) as a vector for inoculation of red spruce (Picea rubens) seedlings with ectomycorrhizal fungi. Sydowia $57(2)$ : $166-178$.

CareY, A.B. 1995. Sciurids in Pacific Northwest managed and old growth forests. Ecological Applications 5: 648-661.

Carey, A.B., W. Colgan III, J.M. Trappe, and R. Molina. 2002. Effect of forest management on truffle abundance and squirrel diets. Northwest Science 76: $148-157$.

Castellano, M.A. 1988. The taxonomy of the genus Hysterangium (Basidiomycotina, Hysterangiaceae) with notes on its ecology. Doctoral dissertation, Oregon State University, Corvallis, OR. 232 pp.

Castellano, M.A., J.M. Trappe, Z. Maser, and C. Maser. 1989. Key to spores of the genera of hypogeous fungi of north temperate forests with special reference to animal mycophagy. Mad River Press, Inc., Eureka, CA. 186 pp.

Clarkson, D.A., and L.S. Mills. 1994. Hypogeous sporocarps in forest remnants and clearcuts in southwest Oregon. Northwest Science 68:259-265.

Colgan, W., III, A.B. Carey, and J.M. Trappe. 1997. A reliable method of analyzing dietaries of mycophagous small mammals. Northwestern Naturalist 78:65-69.

Currah, R.S., E.A. Smreciu, T. Lehesvirta, M. Niemi, AND K.W. LARSEN. 2000. Fungi in the winter diets of northern flying squirrels and red squirrels in the boreal mixed wood forest of northeastern Alberta. Canadian Journal of Botany 78:1514-1520.

Dodge, C.W., AND S.M. ZeLLeR. 1934. Hymenogaster and related genera. Annals of Missouri Botanical Garden 21:627-709.

GILKEY, H.M. 1939. Tuberales of North America. Oregon State Monographs No. 1, Corvallis, OR. 63 pp.

Gomez, D.M., R.G. ANTHONY, AND J.P. HAYES. 2005. Influence of thinning of Douglas-fir on population parameters and diet of northern flying squirrels. Journal of Wildlife Management 69:1670-1682.

HaLL, D. 1991. Diet of northern flying squirrels at Sagehen Creek, California. Journal of Mammalogy 72: 615-617.

Holloway, G.L., and J.R. Malcolm. 2006. Sciurid habitat relationships in forests managed under selection and shelterwood silviculture in Ontario. Journal of Wildlife Management 70:1735-1745.

Hunt, G.A., AND J.M. Trappe. 1987. Seasonal hypogeous sporocarp production in a western Oregon Douglasfir stand. Canadian Journal of Botany 65:438-445.

JoHnSON, C.N. 1996. Interactions between mammals and ectomycorrhizal fungi. Trends in Ecology and Evolution 11:503-507.

Krueger, E. 2004. Distribution and habitat associations of northern flying squirrels in the northern Black Hills of South Dakota. South Dakota Game, Fish and Parks Report. 85 pp.

Lehmkuhl, J., L.E. Gould, E. Cazares, and D.R. HosFORD. 2004. Truffle abundance and mycophagy by northern flying squirrels in eastern Washington forests. Forest Ecology and Management 200:49-65.

Loeb, S., F. Tainter, and E. Cazares. 2000. Habitat association of hypogeous fungi in the southern Appalachians: implications for the endangered northern flying squirrel (Glaucomys sabrinus coloratus). American Midland Naturalist 144:286-296. 
Maser, C., Z. Maser, J.W. Witt, and G. Hunt. 1986. The northern flying squirrel: a mycophagist in southwest Oregon. Canadian Journal of Zoology 64:2086-2089.

Meyer, M.D., D.A. Kelt, AND M.P. NoRTh. 2007. Microhabitat associations of northern flying squirrels in burned and thinned forest stands of the Sierra Nevada. American Midland Naturalist 157:202-211.

Meyer, M.D., AND M.P. NorTh. 2005. Truffle abundance in riparian and upland mixed-conifer forest of California's southern Sierra Nevada. Canadian Journal of Botany 83:1015-1020.

Meyer, M.D., M.P. NorTh, And D.A. Kelt. 2005. Fungi in the diets of northern flying squirrels and lodge pole chipmunks in the Sierra Nevada. Canadian Journal of Zoology 83:1581-1589.

Mitchell, D. 2001. Spring and fall diet of the endangered West Virginia northern flying squirrel (Glaucomys sabrinus fuscus). American Midland Naturalist 146:439-443.

North, M., And J. Greenberg. 1998. Stand conditions associated with truffle abundance in western hemlock/Douglas-fir forests. Forest Ecology and Management 112:55-66.

PoHL, R.W. 1965. Dissecting equipment and materials for the study of minute plant structures. Rhodora 67: 95-96.

Pyare, S., AND W. LONGLAND. 2002. Interrelationships among northern flying squirrels, truffles, and microhabitat structure in Sierra Nevada old-growth habitat. Canadian Journal of Forest Research 32:1016-1024.

Pyare, S., AND W.S. LONGLAND. 2000. Patterns of ectomycorrhizal fungal consumption by small mammals in remnant old-growth forests of the Sierra Nevada. Journal of Mammalogy 82:681-689.

RoHLF, FJ. 2005. NTSYSpc 2.2. Exeter Software, Setauket, New York.

Rosentreter, R., G. HaYward, AND M. WiCKLOW-Howard 1997. Northern flying squirrel seasonal food habits in the interior conifer forests of central Idaho, USA. Northwest Science 71:97-101.

Smith, J.E., R. Molina, M.P. Huso, D.L. Luoma, D. MCKay, M.A. Castellano, T. Lebel, and Y. ValaCHOVIC. 2001. Species richness, abundance, and composition of hypogeous and epigeous ectomycorrhizal fungal sporocarps in young, rotation-age and old-growth stands of Douglas-fir (Pseudotsuga menziesii) in the Cascade Range of Oregon, U.S.A. Canadian Journal of Botany 80:186-204.
SMITH, W.P. 2007. Ecology of Glaucomys sabrinus: habitat, demography and community relations. Journal of Mammalogy 88:862-881.

STATES, J. 1983. New records of hypogeous ascomycetes in Arizona. Mycotaxon 16:396-402

1984. New records of false truffles in pine forests of Arizona. Mycotaxon 19:351-367.

States, J., AND W.S. Gaud. 1997. Ecology of hypogeous fungi associated with ponderosa pine. I. Patterns of distribution and sporocarp production in some Arizona forests. Mycologia 89:712-721.

Stewart, E.L. 1974. The genus Gautieria Vitt. (Hymenogastrales-Basidiomycetes). Doctoral dissertation, Oregon State University, Corvallis, OR. 210 pp.

Thysell, D., L. VILLA, AND A. CAREY. 1997. Observations of northern flying squirrel feeding behavior: use of non-truffle food items. Northwestern Naturalist 78: 87-92.

TrimarCHI, S.D. 1997. A climatology of the Black Hills region. Master's thesis, South Dakota School of Mines and Technology, Rapid City, SD. 218 pp.

VANDER WALL, S. 1998. Foraging success of granivorous rodents: effects of variation in seed and soil water on olfaction. Ecology 79:233-241.

2000. The influence of environmental conditions on cache recovery and cache pilferage by yellow pine chipmunks (Tamias amoenus) and deer mice (Peromyscus maniculatus). Behavioral Ecology 11:544-549.

Vernes, K., S. Blois, AND F. BARlocher. 2004. Seasonal and yearly changes in consumption of hypogeous fungi by northern flying squirrels and red squirrels in old-growth forest, New Brunswick. Canadian Journal of Zoology 82:110-117.

Waters, J.R., K.S. McKelvey, and C. Zabel. 1994. The effects of thinning and broadcast burning on sporocarp production of hypogeous fungi. Canadian Journal of Forest Research 24:1516-1522.

WEIGL, P.D. 2007. The northern flying squirrel (Glaucomys sabrinus): a conservation challenge. Journal of Mammalogy 88:897-907.

Wheatley, M. 2007. Fungi in summer diets of northern flying squirrels (Glaucomys sabrinus) within managed forests of western Alberta, Canada. Northwest Science 81:265-273.

Received 7 November 2008 Accepted 3 September 2009 